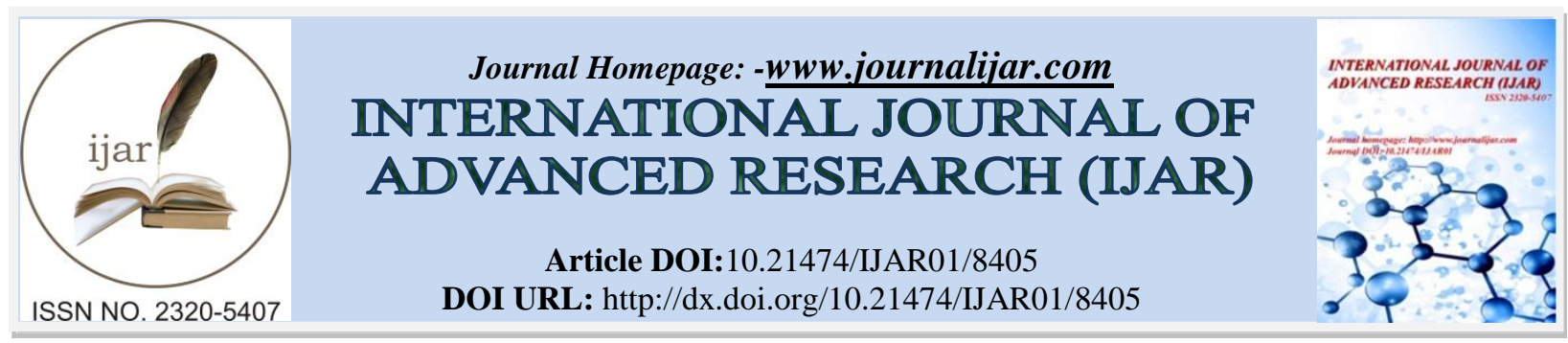

RESEARCH ARTICLE

\title{
PRODUCTION OF BACTERIAL CELLULOSE FROM INDUSTRIAL WASTES USING THE BACTERIAL STRAIN ISOLATED FROM KOMBUCHA.
}

\author{
Shrouk S. Mohamed ${ }^{1}$, Reyad M. El-sharkawy ${ }^{1}$, Mahmoud M. Amer ${ }^{1}$, Enas A. Hassan ${ }^{2}$, NA El-Wakil ${ }^{2}$ and \\ Sohier S.Abd-El Salam ${ }^{1}$. \\ 1. Department of Microbiology, Faculty of Science, Benha University, Egypt. \\ 2. Cellulose and Paper Department \& Centre of Excellence for advanced Sciences, National Research Centre, \\ Egypt.
}

\section{Manuscript Info}

…......................

Manuscript History

Received: 14 November 2018

Final Accepted: 16 December 2018

Published: January 2019

Key words:-

Acetobacter pasteurianus. Bacterial cellulose Kombucha . Fourier transform infrared spectroscopy. Scanning electron microscopy.

\section{Abstract}

Background and Aim: Bacterial cellulose (BC) is a highly pure polymer produced by different bacterial species as Acetobacter, Gluconobacter, pseudomonas and Sarcina. Because of its unique properties, it has been used in different industrial applications. Kombucha tea (KT) is a popular drink that is obtained from the fermentation of a sugared black tea with a precultured tea fungus sample which is a symbiotic association of bacteria and yeasts; forming a thick pellicle of $\mathrm{BC}$ as a secondary metabolite. Using $\mathrm{BC}$ on a large scale in different industries is limited because of the high costs of production process and the low yield of the produced BC. Scientists began to use different wastes as alternative carbon and nitrogen sources to decrease the costs of the production process. So, the aim of this study was the isolation and identification of cellulose producing bacteria from kombucha tea, testing the efficiency of the isolated bacterial strain in producing $\mathrm{BC}$ in media formulated with treated beet molasses or acid whey as a carbon source and corn steep liquor as a nitrogen source, evaluation of the produced BC paper sheet of the media with the highest yield in terms of Scanning Electron Microscopy (SEM), Fourier Transform Infrared Spectroscopy (FT-IR), X-Ray Diffraction, tensile strength and degree of polymerization.

Methods using: Isolation of the bacteria responsible for producing cellulose from kombucha tea using the Hestrin- Schramm (HS) and $\mathrm{CaCo}_{3}$ media, the identification of bacterial isolate according to its morphological, biochemical characteristics and molecular character ization using the 16S rRNA gene sequence, production of BC using the isolated bacterial strain on media formulated with different industrial wastes, characterization of the produced $\mathrm{BC}$ with the highest yield by SEM, FT-IR and with X-Ray Diffraction. Determination of the tensile strength and the degree of polymerization of the $\mathrm{BC}$ paper sheet.

Results: The morphological, biochemical characterization revealed that the isolated bacteria belongs to the Acetobacter sp. The identification using the 16S rRNA indicated that the gene sequence of the isolated bacteria was very similar to the Acetobacter Pasteurianus IFO 
3283- 01. The highest yield of BC was obtained in the TMCSL media ( $7 \mathrm{~g} / \mathrm{l})$, followed by that obtained in AWCSL media $(5.83 \mathrm{~g} / \mathrm{l})$. The BC paper sheet produced in TMCSL media was characterized where the SEM analysis showed the high porosity, three dimensional structure of the produced BC. The BC paper sheet was characterized by high degree of polymerization (2597), high crystallinity (88.9\%) and high tensile strength value (96.72 $\mathrm{MPa})$.

Conclusions: According to the obtained results, it was concluded that using low cost wastes as treated molasses; acid whey and corn steep liquor as alternative carbon and nitrogen sources for producing BC decreased the production costs and increased the yield of the obtained BC. Also, the strain Acetobacter Pasteurianus IFO 3283-01 isolated from kombucha tea gave high yield of BC in the TMCSL media, this BC paper sheet was characterized by high crystallinity, high tensile strength and high DP value. Considering these obtained results, the produced $\mathrm{BC}$ can be used in different industrial applications because of its unique properties.

Copy Right, IJAR, 2017,. All rights reserved.

\section{Introduction:-}

Cellulose is the most wide spreaded homopolysaccharide in nature (Lin et al., 2014), it consists of repeating units of the monosaccharide D-glucose which are linked together by $\beta(1,4)$ linkage. Most of the cellulose used in industrial applications is from plant origin (Brown, 2004), but the continuous extraction of cellulose from plants cause decreasing in the cultivable areas causing imbalance in the environment (Park et al., 2003). In addition to that plant cellulose is impure as it is combined with hemicellulose and lignin (Jung et al., 2005) and need high costs to purify it. So, scientists began to incorporate BC in different industries instead of plant cellulose (Lin et al., 2013) because of its unique properties as high crystallinity, high purity, high degree of polymerization, high tensile strength and high water holding capacity (Lin et al., 2014; Ul-Islam et al., 2012).

Kombucha tea (KT) is a popular drink that is obtained from the fermentation of a sugared black tea with a tea fungus that is a symbiotic association of acetic acid bacterial species as Acetobacter; Gluconobacter; Komatiobacter; Sarcina; pseudomonas species and yeast species as Saccharomyces; Zygosaccharomyces (Watawana et al., 2016), Candida or Torutospora (Marsh et al., 2014) for 14 days (Jayabalan et al., 2014). Ethanol and many organic acids as gluconic acids, acetic acid and lactic acid are the main metabolites in the broth (Vina et al., 2013). At the end of the fermentation time, a thick pellicle of cellulose was formed at the surface of tea broth as a secondary metabolite (Watawana et al., 2016).

Using BC on a large industrial scale is limited (Moon et al., 2006) because of the high costs of production process that reachs to about $65 \%$ of the total production costs and the low yield of the produced BC (Koutinas et al., 2012). Using different agro-industrial wastes in the fermentation media for production of BC solve some environmental issues as they cause a reduction in the cost of producing cellulose (Kiziltas et al., 2015), decreasing the environmental pollution which result from wastes accumulation in nature (Arauz et al., 2009) and these wastes contain many nutritional supplements which increase the yield of the produced cellulose (Cakar et al., 2014). Many wastes have been used as carbon sources as they are rich in sugars which can be easily used by microorganisms as an energy source (Rosales et al., 2005) such as bagasse hydrolysate (Cheng et al., 2017), the pullulan fermentation waste water (Zhao et al., 2018); glycerol remaining from biodiesel production and grape bagasse from wine production (Vazquez et al., 2013); coffee cherry husk extract (Rani et al., 2013); Coconut water (Watawana et al., 2015).

In this study, Molasses which is the by-product obtained from the production of sugar from cane or beet has been used as alternate carbon source of its low cost and the presence of important components, as organic compounds, proteins, minerals and vitamins which are very useful for the fermentation process (Rodrigues et al., 2006). It has been used as excellent carbon source as reported in (Keshk and Sameshima, 2006; Malbasa et al., 2008; Singh et al., 2017; Tyagi et al., 2015). Acid whey which is the liquid fraction remains from the cheese manufacture process from milk has been used as a carbon source or a nutrient medium as it contains many valuable nutritional components like 
lactose, amino acids, many minerals and some group B vitamins as reported by (Jozala et al., 2015; Swanporsi et al., 2014). Corn steep liquor is the by-product obtained from the production of starch from corn also has been used as alternate nitrogen source in the culture medium as it contains some essential amino acids, few carbohydrates, some vitamins and mineral salts which are essential to most of the bacteria as mentioned by (Rani et al., 2011; Vazquez et al., 2013). Costa et al. (2017) reported that using CSL as an alternative nitrogen source in the medium caused an increasing in the yield of the cellulose as it contains lactate which induces the production of BC.

The aim of this study was the isolation and identification of cellulose producing bacteria from kombucha tea, testing the efficiency of the isolated bacterial strain in producing bacterial cellulose in media formulated with treated beet molasses or acid whey as a carbon source and corn steep liquor as a nitrogen source, evaluation of the produced BC paper sheets of the media with the highest yield in terms of SEM analysis, FT-IR Spectroscopy, X-Ray Diffraction, tensile strength and degree of polymerization.

\section{Materials and Methods:-}

Isolation of bacteria responsible for BC production:-

For the isolation of cellulose producing bacteria from the kombucha tea fungus, a kombucha tea fungus sample from a previously prepared KT was cut into very small pieces, a sterile saline was added to it in sterilized conditions and then they were shaked for 24 hours at $30^{\circ} \mathrm{C}$. The obtained cell suspension was serially diluted and then cultivated in Hestrin Schramm medium (HS medium) that consists of glucose (20 gm),yeast extract (5 gm), peptone (5 gm), $\mathrm{Na}_{2} \mathrm{HPO}_{4}(5 \mathrm{gm})$, citric acid $(1.15 \mathrm{gm})$ and agar $(20 \mathrm{gm})$, all were dissolved in 1 litre distilled water, $\mathrm{pH}$ of the media was adjusted to (6) by using $1 \mathrm{~N}$ acetic acid and the cell suspension was also cultivated in Gluconobacter Oxydans medium that consists of Glucose $(100 \mathrm{gm})$, yeast extract $(10 \mathrm{gm}), \mathrm{CaCo}_{3}(20 \mathrm{gm})$ and agar $(20 \mathrm{gm})$ and all were dissolved in 1 litre distilled water, $\mathrm{pH}$ of the medium was adjusted to (6.8) by using $1 \mathrm{~N}$ acetic acid. About $0.1 \mathrm{~g} / \mathrm{l}$ of the antibiotic cycloheximide was added to each media to prevent the growth of the yeast cells. Then the petriplates were inoculated and incubated at $30^{\circ} \mathrm{C}$ for $2-3$ days.

\section{Identification of the isolated cellulose producing bacteria:-}

Morphological and biochemical characterization of the isolated bacteria:-

The bacterial isolate was identified based on its morphological and biochemical characterization. The morphological characterization of bacterial cells and colonies was determined under $400 \mathrm{X}$ magnifications including gram stain test, morphology and size of the cells. The biochemical characterization of the bacterial isolate include many tests as "catalase test, oxidase test, methyl red test, indole production test, oxidation of acetate, oxidation of lactate and over oxidation of ethanol which were performed according to methods in the Bergey's Manual of Systematic Bacteriology (Kadere et al., 2008). The bacterial isolate was preserved by subculturing in HS agar slants for further investigations.

\section{Molcular identification of bacteria:-}

The isolated bacterial strain was identified using the $16 \mathrm{~S}$ rRNA sequences analysis. Firstly, the genomic DNA of the bacterial cells were extracted using the forward primer (5 'AGAGTTTGTCCTGGCTCAG3') and the reverse primer (5'TAAGGAGGTGATCCAGGC3`) for PCR analysis. RCR reaction was performed in volume $50 \mu \mathrm{L}$ by the following settings: one initial denaturation cycle at $95^{\circ} \mathrm{C}$ for 10 minutes, 40 amplification cycles $\left(95^{\circ} \mathrm{C}\right.$ for $30 \mathrm{Sec}$, $65^{\circ} \mathrm{C}$ for $1 \mathrm{~min}$ and $72^{\circ} \mathrm{C}$ for $1.5 \mathrm{~min}$ ), for denaturation, annealing and extension respectively. At last, a final extension occurred for $10 \mathrm{~min}$ at $72^{\circ} \mathrm{C}$. The PCR product was run in $1.2 \%$ agarose gel for $1.5 \mathrm{~h}$ at $100 \mathrm{~V}$, stained in $0.5 \mu \mathrm{g} / \mathrm{ml}$ ethidium bromide solution and then the PCR product was purified and sequenced using the forward and reverse primers.

The 16S rRNA sequence read was analyzed using BLAST (Nithya and Bhaskar, 2013) and was aligned against National Center for Biotechnology Information (NCBI) Genbank (US National Library of medicine, Bethesda, Mary-Land, USA) databases to identify the $16 \mathrm{~S}$ rRNA read.

\section{Production of bacterial cellulose in media contained wastes:-}

The isolated bacterial strain was inoculated in $100 \mathrm{ml}$ volume of media formulated from $10 \%$ treated molasses with $1 \mathrm{~N} \mathrm{H}_{2} \mathrm{SO}_{4}(\mathrm{TM})$ as a carbon source and $1 \%$ corn steep liquor (CSL) as a nitrogen source and also in another media of $100 \mathrm{ml}$ volume formulated from $10 \%$ acid whey (AW) as a carbon source and 1\% corn steep liquor as a nitrogen source. The two media were incubated at $30^{\circ} \mathrm{C}$ for 14 days in static conditions. After the incubation period, the bacterial cellulose pellicles were harvested from the media, rinsed with distilled water and gently dried between two 
tissue papers to remove the excess water and weighted to determine the wet weight. To detect the yield of the produced $\mathrm{BC}$, the pellicles were dried in an oven at $60^{\circ} \mathrm{C}$ till constant weight and weighed to determine it.

\section{Purification of the produced bacterial cellulose:-}

The produced $\mathrm{BC}$ pellicle was washed many times with distilled water then boiled with $1 \mathrm{~N} \mathrm{NaOH}$ for 30 minutes at $90^{\circ} \mathrm{C}$ (Keshk and Sameshima, 2005) and after that the pellicle was washed again with distilled water and rinsed in water over night then it was squeezed using a presser for 4 minutes at $40 \mathrm{Kg} / \mathrm{cm}^{2}$, then dried at $100^{\circ} \mathrm{C}$ in a rotating drum to obtain the BC paper sheet.

Characterization of the produced bacterial cellulose:-

The paper sheet of the $\mathrm{BC}$ pellicle with the highest yield was characterized using:

Scanning electron microscopy (SEM):-

SEM was performed for the BC sheet to study the morphology and the surface of the samples using a Jeol JXA $840 \mathrm{~A}$ system running at 5-10 keV. Before scanning, the sample was coated with gold using a sputter coater system (Edwards Sputter Coater, UK).

\section{X-Ray diffraction:-}

$\mathrm{X}$-ray diffraction (XRD) patterns were recorded by an X-ray diffractometer BRUKER D8 advanced Cu target, wavelength $1.54 \mathrm{~A}, 40 \mathrm{kV}$ and $40 \mathrm{~mA}$, Germany. The crystallinity index of the bacterial cellulose sample is

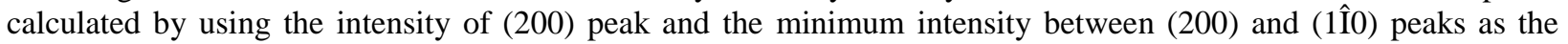
intensity of (200) peak represents both crystalline and amorphous parts, while the minimum intensity represent the amorphous part. The crystallinity index CrIcan be calculated by the equation:

$\mathrm{CrI}=\left[\left(\mathrm{I}_{200}\right)-\left(\mathrm{I}_{\mathrm{am}}\right) /\left(\mathrm{I}_{200}\right)\right]^{*} 100(1)$

Where $\mathrm{I}_{200}$ is the intensity at 200 peak and $\mathrm{I}_{\mathrm{am}}$ is the minimum intensity between (110) and (200) peaks (Segal et al., 1959).

\section{Fourier Transform Infrared Spectroscopy (FTIR):-}

FT-IR spectroscopy is primarily used to identify the chemical structure of BC. FTIR spectra were obtained on VERTEX 70 FTIR spectrometer from Bruker, Germany equipped with ATR diamond crystal system in the spectral range 4000-400 cm-1 and resolution of $4 \mathrm{~cm}^{-1}$.

Determination of the mechanical properties of the paper sheet:-

The following parameters were examined in the produced $\mathrm{BC}$ sheet:

\section{Tensile strength:-}

It was carried out according to TAPPI T494 (TAPPI 2006) using a Lloyd instrument (Lloyd Instruments, West Sussex, United Kingdom) with a 100-N load cell. The measurements were performed at room temperature $\left(\sim 25^{\circ} \mathrm{C}\right)$ with a crosshead speed of $2 \mathrm{~mm} / \mathrm{min}$; five replicates were tested for each film. The sample dimensions were $20 \mathrm{~mm}$ long and $5 \mathrm{~mm}$ wide. Film thickness was measured to the nearest $0.001 \mathrm{~mm}$ with a hand-held digimatic micrometer (Quantu Mike Mitutoyo). Four thickness measurements at different positions were taken on each specimen, being in the range of 0.15 to $0.2 \mathrm{~mm}$.

\section{Determination of the degree of polymerization:-}

Here, we used the solution Bis (ethylene diamine) copper (II) hydroxide as a solvent for BC paper sheet and the degree of polymerization was determined using a capillary viscometer [TAPPI test method T $230 \mathrm{om}-89$ ] and by using the obtained viscosity values, the degree of polymerization was calculated.

\section{Results and discussion:-}

The bacterial strain was isolated from kombucha tea; it was characterized as gram negative, short rod shaped bacteria. The bacterial isolate was positive for catalase test, negative for oxidase test, gave positive result with Methyl Red test and gave negative result with Indole test. It can oxidise lactate and acetate, also it can overoxidise ethanol into $\mathrm{CO}_{2}$ and $\mathrm{H}_{2} \mathrm{O}$. The obtained characteristics of morphological and biochemical identification were compared with the data in Bergey's Manual of Systematic Bacteriology as it was indicated that the bacterial strain belonged to the genus Acetobacter. 
The obtained 16S rRNA sequence read was identified using the Basic Local Alignment Search Tool (BLAST) as it was aligned against the National Center for Biotechnology Information (NCBI) Genbank databases (US National Library of medicine, Bethesda ,Mary-Land ,USA) to identify the 16S rRNA read. BLAST results showed that the bacterial strain showed 99\% homology with the bacterial strain Acetobacter pasteurianus IFO 3283-01 and the phylogenetic tree was constructed using the $16 \mathrm{~S}$ rRNA gene sequences of the isolated bacteria as shown in figure (1).

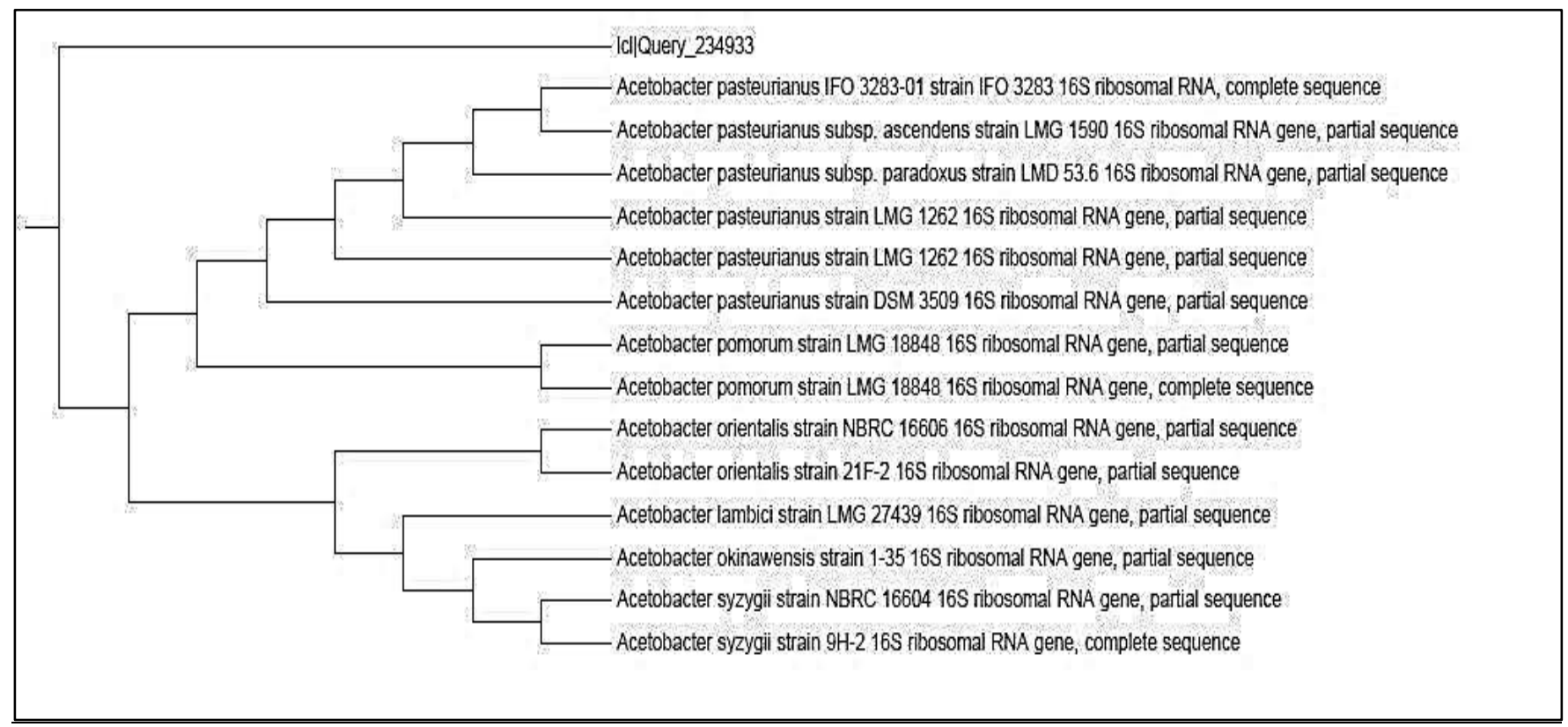

Figure 1:- Phylogenetic tree of Acetobacter pasteurianus based on the 16S rRNA sequence

The efficiency of the isolated bacteria to produce cellulose was tested by inoculating it in media of $100 \mathrm{ml}$ volume formulated from $10 \%$ treated molasses or acid whey as a carbon source and $1 \%$ corn steep liquor as a nitrogen source, the two culture media were incubated for 14 days at $30^{\circ} \mathrm{C}$ in static conditions. At the end of the incubation period, it was detected that the yield of BC in treated molasses- corn steep liquor (TMCSL) media and in acid wheycorn steep liquor (AWCSL) medium was $7 \mathrm{~g} / 1$ and $5.83 \mathrm{~g} / \mathrm{l}$, respectively. The pellicle with the highest yield that was obtained in TMCSL media was purified, pressed and dried to obtain the BC paper sheet. The obtained results were higher than that reported by (Raghunathan, D., 2013) who indicated that $1.68 \mathrm{~g} / \mathrm{l}$ of BC was produced by Acetobacter sp.DR-1 in $100 \mathrm{ml}$ of sugar cane juice at $30^{\circ} \mathrm{C}$ for 7 days.

Bae and Shoda, (2005) reported that $\mathrm{H}_{2} \mathrm{SO}_{4}$ treated molasses was used as a carbon source for the production of bacterial cellulose by Acetobacter xylinum BPR2001 in a jar fermentor, the BC yield was about $76 \%$ higher than that produced by using unclarified molasses and the growth rate increased 2 fold.

SEM image of the BC paper sheet produced from TMCSL medium as shown in figure (2) is characterized by ultrafine three dimensional interwoven network of cellulose nanofibers in the range of 29-72 $\mathrm{nm}$ with plenty of connected pores which have different diameters. The results are in agreement with (Vazquez et al., 2013) where BC nanofibers produced by Gluconacetobacter Xylinus on Hestrin Schramm media containing grape bagasse and glycerol for 14 days were in the range of 30-80 nm and with (Cheng et al., 2017) who reported that BC nanofibers produced by Acetobacter xylinum on media containing bagasse hydrolysateas carbon source for 10 days at $30^{\circ} \mathrm{C}$ were in the range of $30-80 \mathrm{~nm}$. 


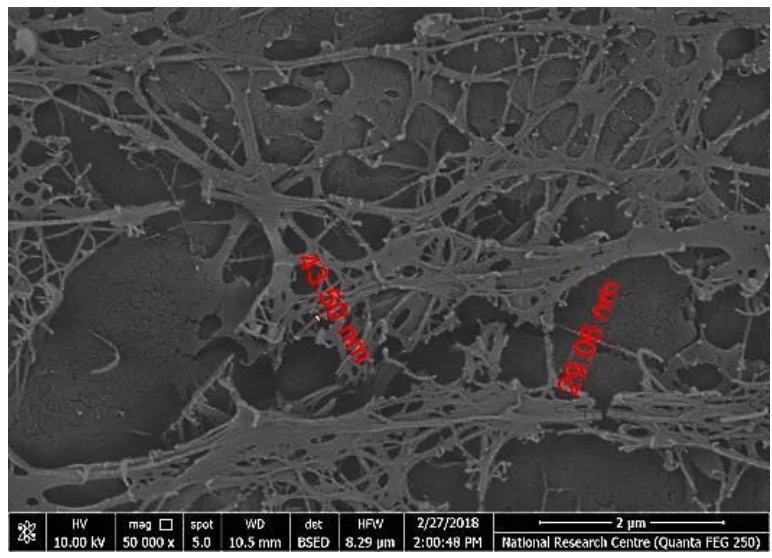

Figure 2:-SEM images of BC paper sheet produced by Acetobacter pasteurianus grown in TMCSL media.

The FT-IR Spectroscopy was used to indicate the peaks of the BC sheet which are attributed to different functional groups found on native cellulose. The FT-IR spectrum between 4000 and $400 \mathrm{~cm}^{-1}$ contains several characteristic peaks as presented in figure (3). Spectrum of BC showed a broad band between 3,300 and 3,400 $\mathrm{cm}^{-1}$ due to the presence of the $\mathrm{O}-\mathrm{H}$ stretching vibration, indicating strong hydrogen bonding, the band at $2,890 \mathrm{~cm}^{-1}$ which represent the aliphatic $\mathrm{C}-\mathrm{H}$ stretching vibration, the band between $1,650 \mathrm{~cm}^{-1}$ and $1,428 \mathrm{~cm}^{-1}$ which represent the hydrogen-bonded carbonyl stretching vibration, the band at $1,159 \mathrm{~cm}^{-1}$ is assigned to the cellulose $\mathrm{C}-\mathrm{O}-\mathrm{C}$ stretching vibrations, the band at $896 \mathrm{~cm}^{-1}$ which is assigned to the $\beta$-linked glucose polymers and the band at $680 \mathrm{~cm}^{-1}$ which represent the $\mathrm{OH}$ out-of-phase bending vibrations. The obtained results are consistent with the results reported by (Gayathry\& Gopalaswamy, 2014) who mentioned that the FTIR band centered at around 2,890 $\mathrm{cm}^{-1}$ is attributed to the aliphatic $\mathrm{C}-\mathrm{H}$ stretching vibration. The band at to $1,644 \mathrm{~cm}^{-1}$ is attributed to the $\mathrm{H}-\mathrm{O}-\mathrm{H}$ bending vibration of absorbed water molecules. The band at $1,428 \mathrm{~cm}^{-1}$ is due to the $\mathrm{CH}_{2}$ symmetrical bending or surface carboxylate groups. All of these data approved that the obtained BC sheet is very similar to pure cellulose.

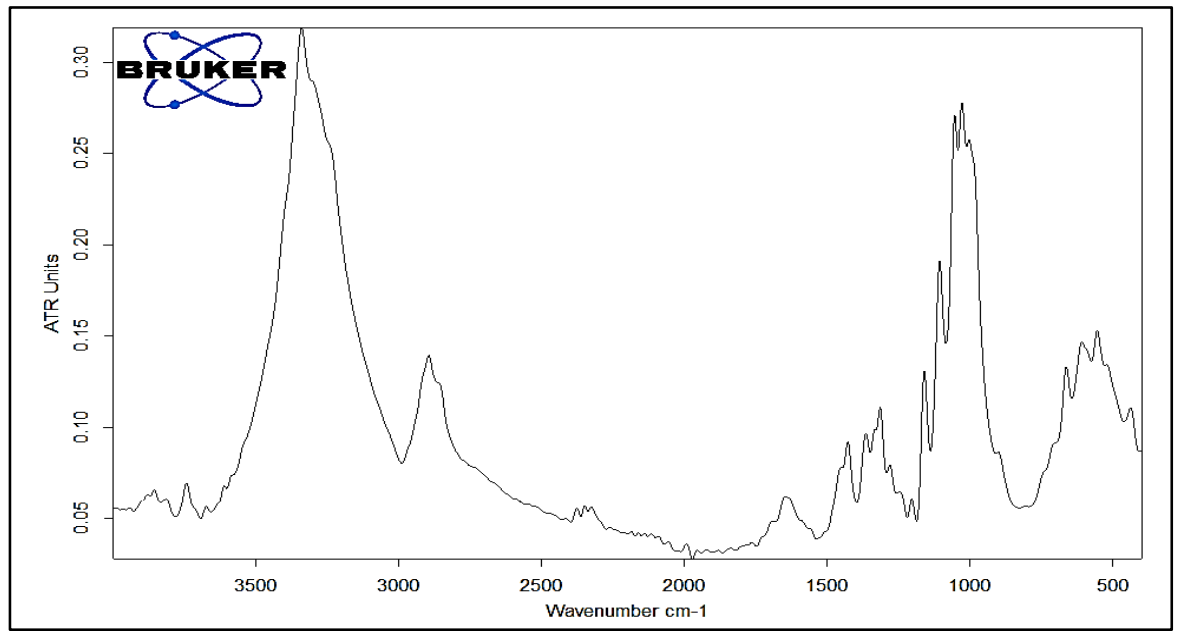

Figure 3:-FT-IR spectra of BC sheet produced by Acetobacter pasteurianus grown in TMCSL media.

X-Ray diffraction pattern of the BC produced from TMCSL medium is represented in Figure (4). The X-ray diffraction patterns of the mentioned $\mathrm{BC}$ sample showed diffraction peaks at $2 \Theta(14.9,23.1)$. The main diffraction peaks found on the sample was identical to the main characteristic peaks of native cellulose I as they are assigned to the peaks (1) 10$),(110)$ and (200) reflection planes of cellulose I. The XRD pattern of BC is in agreement with the typical profile of cellulose I allomorph (Maeda et al., 2006). The produced sample is characterized by high crystallinity $(88.9 \%)$ when compared with the crystallinity index of plant cellulose that represents about $40-60 \%$ (Mohite\& Patil, 2014) and 79\% for Kombucha-synthesized bacterial cellulose (Changlai et al., 2014). The obtained crystallinity index value was close to results reported by (Vazquez et al. (2013) reported that the CrI values of BC obtained by Gluconacetobacter xylinus NRRL B-42 using media contained glucose, commercial glycerol, glycerol from Biodiesel, grape bagasse or cane molasses as carbon sources were $92 \%, 95 \%, 94 \%, 89 \%$ and $89 \%$ respectively. 
The obtained CrI value was higher than that obtained by (Mohammadkazemi et al., 2015) who reportedthat the CrI value of BC produced by Gluconacetobacter xylinus PTCC1734 on media contained mannitol and sucrose was $46.7 \%$ and $65.5 \%$ respectively.

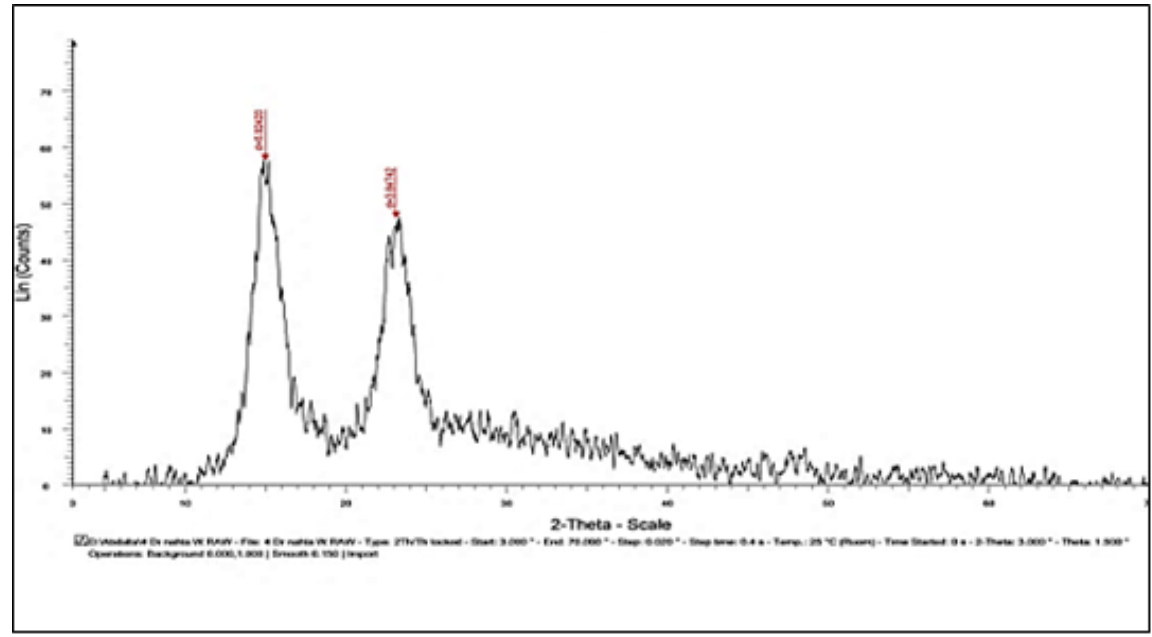

Figure 4:-X- Ray of BC sheet produced by Acetobacter pasteurianus grown in TMCSL media.

The DP of the BC under investigation was 2597. The obtained high DP value was close to results reported by (Gayathry\& Gopalaswamy, 2014) who reported that the DP value of bacterial cellulose produced by Acetobacter Xylinum sju-1 in HS medium was 2074. Keshk and Sameshima, (2006) mentioned that the DP value of bacterial cellulose produced by Acetobacter Xylinum ATCC 10245 in HS medium or HS medium supplemented with 1\% lignosulfonates was 2681. Also, (Tsouko et al., 2015) reported that high DP values of BC obtained by Komagataeibacter sucrofermentans DSM 15973 in HS media contained crude glycerol, biodiesel industry byproducts or confectionery industry waste streams respectively instead of glucose.

The tensile strength of BC produced TMCSL medium was $96.72 \mathrm{MPa}$. The result was close to that obtained by Komagataeibacter sucrofermentans DSM 15973 in media contained crude glycerol mixed with Sun Flower Meal hydrolysate or contained Flour-rich waste hydrolysate (Tsouko et al., 2015).

\section{Conclusions:-}

On the basis of the obtained results, it can be concluded that the many industrial wastes as treated molasses, acid whey and corn steep liquor are a promising substrates for obtaining $\mathrm{BC}$ as using them minimize the production costs of BC. The bacterial strain Acetobacter pasteurianus isolated from kombucha gave a high yield of BC about $7 \mathrm{~g} / 1$ in TMCSL media after 14 days of incubation at $30^{\circ} \mathrm{C}$ in static conditions. The obtained paper sheet was characterized by high crystallinity index value and three dimensional structure of the cellulose nanofibers with high DP value.

\section{Recommendation:}

The outcome of this investigation provides an alternate cost effecting medium for producing BC by the isolated bacteria from kombucha with unique properties which can be used in different applications as paper and textile industries because of its high tensile strength and high mechanical properties besides utilizing these wastes cause reduction in the environmental pollution and preventing its accumulation in nature.

\section{References:-}

1. Arauz, L.J.; Jozala, A.F.; Mazzola, P.G. and Penna, T.C.V. (2009). Nisin biotechnologicalproduction and application: a review. Trends Food Sci Tech20:146-154. doi: 10.1016/ j.tifs.2009.01.056.

2. Bae, S.O. and Shoda, M. (2005). Production of bacterial cellulose by Acetobacter xylinum BPR2001 using molasses medium in a jar fermentor. Appl. Microbiol. Biotechnol. 67(1): 45-51.

3. Brown, R.M.J.R. (2004). Cellulose structure and biosynthesis: what is in store for the 21 st century? Journal of Polymer Science Part A: Polymer Chemistry, 42(3), 487-495. 
4. Cakar, F.; Özer, I.; Aytekin, A.Ö. and Sahin, F. (2014). Improvement production of bacterial cellulose by semicontinuous process in molasses medium. Carbohydr. Polym.106, 7-13. doi: 10.1016/j.carbpol.2014. 01.103.

5. Changlai, Z.; Feng, L.; Xinyang, Z.; Lin, L.; and Zhang, T. (2014). Kombucha-synthesized bacterial cellulose: Preparation, characterization and biocompatibility evaluation. Journal of Biomedical Materials Research.2014; 102A: $1549-1557$.

6. Cheng, Z.; Yang, R.R. and Liu, X. (2017). Production of bacterial cellulose by Acetobacter Xylinum through utilizing Acetic Acid Hudrolysate of Bagasse as Low-cost carbon source. BioResources 12(1), 1190-1200.

7. Costa, A.F.S; Almeida, F.C.G.; Vinhas, G.M. and Sarubbo, L.A. (2017). Production of Bacterial Cellulose by Gluconacetobacter hansenii Using Corn Steep Liquor As Nutrient Sources Front. Microbiol. 8:2027.doi: $10.3389 /$ fmicb.02027.

8. Gayathry, G. and Gopalaswamy, G. (2014). Production and characterization of microbial cellulosic fibre from Acetobacter xylinum. Indian journal of fibre and textile research, 39: 39-96.

9. Jayabalan, R.; Malbasa, R.V.; Loncar, E.S.; Vitas, J.S. and Sathish kumar, M. (2014). A review on Kombucha Tea - Microbiology, composition, fermentation, beneficial effects, toxicity, and tea fungus. Comprehensive Reviews in Food Science and Food Safety, 13, pp. 538-550. doi: 10.1111/154104337.12073.

10. Jozala, A.F.; Pértile, R.A.; dos Santos, C.A.; et al (2015). Bacterial cellulose production by Gluconacetobacter xylinus by employing alternative culture media. Appl Microbiol Biotechnol.2015;99(3):1181-1190.25

11. Jung, J.K.; Park, and Chang, H.N. (2005). Bacterial cellulose production by Glconoacetobacter hansenii in agitated culture without living non- cellulose producing cells. Enzyme Microb. Technol., 37:347-354.

12. Kadere, T.T.; Miyamoto, T.; Oniang`o, R.K.; Kutima, P.M. andNjoroge, S.M. (2008). Isolation and identification of the genera Acetobacter and Gluconobacter in coconut toddy (mnazi). African J. Biotechnol., 7(1684-5315): 2963-2971.

13. Keshk, S. and Sameshima, K. (2006). The utilization of sugar cane molasses with/ without the presence of lignosulfonate for the production of bacterial cellulose. Appl. Microbiol. Biotechnol. 72(2): 291-296.

14. Keshk, Sh. and Sameshima, K. (2005). Evaluation of different carbon sources for bacterial cellulose production. African J. Biotechnol., 4(6): 478-482.

15. Kiziltas, E.E.; Kiziltas, A. and Gardner, D.J. (2015). Synthesis of bacterial cellulose using hot water extracted wood sugars. Carbohydr. Polym. 124, 131-138.

16. Koutinas, A.A.; Sypsas, V.; Kandylis, P.; Michelis, A.; Bekatorou, A.; Kourkoutas, Y.; Kordulis, C.; Lycourghiotis, A.; Banat, I.M.; Nigam, P.; Marchant, R.; Giannouli, M. and Yianoulis, P. (2012). Nano-tubular cellulose for bioprocess technology development. PLos ONE 7(4): e34350. doi:10.1371 /journal .pone.0034350

17. Lin W C, Lien C C, Yeh H J, Yu C H\& Hsu S H (2013). Bacterial cellulose and bacterial cellulose-chitosan membranes for wound dressing applications. Carbohydr Polym 94:603-611. doi:10.1016/j.carbpol. 2013.01.076.

18. Lin, D.; Lopez-Sanchez, P.; Li, R. and Li, Z. (2014). Production of bacterial cellulose by Gluconacetobacter hansenii CGMCC 3917 using only waste beer yeast as nutrient source. Bioresource Technology, 151, 113-119.

19. Maeda, H.; Nakajima, M.; Hagiwara, T.; Sawaguchi, T. and Yano, S. (2006). Bacterial cellulose/silica hybrid fabricated by mimicking biocomposites. J Mater Sci 2006; 41:5646-5656.

20. Malba `a, R.; Lon`car, E.; Djuri'c, M. and Do`senovi'c, I. (2008). Effect of sucrose conc on concentration on the products of kombucha fermentation on molasses. Food Chem 108:926-32.

21. Marsh, A.J.; Hill, C.; Ross, R.P. and Cotter P.D. (2014). Fermented beverages with health promoting potential: Past and future perspectives. Trends in Food Science \& Technology, 38(2), 113-124. https://doi.org/10.1016/ j.tifs. 2014.05.002.

22. Mohammadkazemia, F.; Azinb, M. and Ashoric, A. (2015). Production of bacterial cellulose using different carbon sources and culture media. CarbohydrPolym. 2015; 117:518-523.

23. Mohite, B. V. and Patil, S. V. (2014).A novel biomaterial: bacterial cellulose and its new era applications. Biotechnol Appl Biochem 61(2):101-110.doi:10.1002/bab.1148.

24. Moon, S.H.; Park, J.M.; Chun, H.Y. and Kim, S.J. (2006). Comparisons of physical properties of bacterial celluloses produced in different culture conditions using saccharified food wastes. Biotechnol. Bioprocess Eng. 2006, 11, 26-31.

25. Nithya, V. and Bhaskar, A. (2013). 16S and 18S rRNA gene sequencing of a typical Clinical Isolated Microorganisms Identified in Keratitis Patients. Inventi Impact: Clin. Res., 1-6.

26. Park, J.K.; Park, Y.H. and Jung, J.Y. (2003). Production of bacterial cellulose by Gluconacetobacter hansenii PJK isolated from rotten apple. Biotechnology and Bioprocess Engineering, 8(2):83-88.

27. Raghunathan, D. (2013). Production of microbial cellulose from the new bacterial strain isolated from temple wash waters. International Journal of Current Microbiology and Applied Sciences. 2013; 2:275-290. 
28. Rani, M.U.; Navin, K.R. and Appaiah, K.A.A. (2013). Statistical optimization of medium composition for bacterial cellulose production by Gluconacetobacter hansenii UAC09 using coffee cherry husk extract-an agroindustry waste. J MicrobiolBiotechnol 21:739.

29. Rodrigues, L.R.; Teixeira, J.A. and Oliveira, R. (2006). Low-cost fermentative medium for biosurfactant production by probiotic bacteria. Biochem Eng J 32:135-42.

30. Rosales, E.; Couto, S.R. and Sanromán, M.A. (2005). Reutilisation of food processing wastes for production of relevant metabolites: application to laccase production by Trametes hirsuta. Journal of Food Engineering, 66(4), 419-423.

31. Segal, L.; Creely, J.; Martin, A.; et al. (1959). An empirical method for estimating the degree of crystallinity of native cellulose using the X-ray diffractometer. Text Res J.; 29: 786-794.

32. Singh, O.; Parmjit, S.; Harish P.K. and Chopra, (2017). Response surface optimization for cellulose production from agro industrial waste by using new bacterial isolate Gluconacetobacter xylinus C18. Food Sci Biotechnol 26(4):1019-1028. DOI 10.1007/s10068-017-0143-x.

33. Suwanposri, A.; Yukphan, P.; Yamada, Y. and Ochaikul, D. (2014). Statistical optimisation of culture conditions for biocellulose production by Komagataeibacter sp PAP1 using soya bean whey. MaejoInt J Sci Technol. 8:1-14.

34. Tsouko, E.; Kourmentza, C.; Ladakis, D.; Kopsahelis, N.; Mandala, I.; Papanikolaou, S.; Paloukis, F.; Alves, V. and Koutinas, A. (2015). Bacterial Cellulose Production from Industrial Waste and by-Product StreamsInt. J. Mol. Sci. 2015, 16, 14832-14849; doi: 10.3390 /ijms 160714832.

35. Tyagi, N. and Suresh, S. (2015). Production of cellulose from sugarcane molasses using Gluconacetobacter intermedius SNT-1: optimization \& characterization, Journal of Cleaner Production, http://dx.doi .org/10 .1016/j.jclepro.2015.07.054.

36. Ul-Islam, M.; Khan, T. and Park, J.K. (2012). Nanoreinforced bacterial cellulose-, montmorillonite composites for biomedical applications. Carbohydrate Polymers, 89(4), 1189-1197.

37. Vazquez, A.; Foresti, M.L.; Cerrutti, P. and Galvagno, M. (2013). Bacterial Cellulose from simple and low cost production media by Gluconacetobacter xylinus. Journal of Polymers and Environment, 21(2), 545-554.

38. Vīna, I.; Semjonovs, P.; Linde, R. and Patetko, A. (2013). Glucuronic acid containing fermented functional beverages produced by natural yeasts and bacteria associations. International Journal of Recent Research and Applied Studies, 14, 17-25.

39. Watawana, M.I.; Jayawardena, N.; Gunawardhana, C.B. andWaisundara, V.Y. (2016). Enhancement of the antioxidant and starch hydrolase inhibitory activities of king coconut water (Cocosnucifera var. aurantiaca) by fermentation with Kombucha "tea fungus."International Journal of Food Science\& Technology, 51(2), 490498. https://doi.org /10.1111/ijfs13006.

40. Watawana, M.I.; Jayawardena, N.; Gunawardhana, C.B. and Waisundara, V.Y. (2015). Health, wellness and safety aspects of the consumption of Kombucha. Journal of Chemistry, 2015, 1-11.https://doi. org/10.1155 /2015/591869.

41. Zhao, H.; Li, J. and Zhu, K. (2018). Bacterial Cellulose Production from Waste products and Fermentation conditions optimization IOP Conf. Series: Materials Science and Engineering 394 (2018) 022041 doi:10.1088/1757-899X/394/2/022041. 